\title{
Middle Paleozoic-Mesozoic boundary of the North Asian craton and the Okhotsk terrane: new geochemical and geochronological data and their geodynamic interpretation
}

\author{
A. V. Prokopiev ${ }^{1}$, J. Toro ${ }^{2}$, J. K. Hourigan ${ }^{3}$, A. G. Bakharev ${ }^{1}$, and E. L. Miller ${ }^{4}$ \\ ${ }^{1}$ Diamond and Precious Metal Geology Institute, Siberian Branch, Russian Academy of Sciences, Yakutsk 677980, Russia \\ ${ }^{2}$ Department of Geology and Geography, West Virginia University, Morgantown, WV 26506, USA \\ ${ }^{3}$ Department of Earth Sciences, University of California, Santa Cruz, CA 95064, USA \\ ${ }^{4}$ Department of Geological and Environmental Sciences, Stanford University, Stanford, CA 94305, USA
}

\begin{abstract}
The Okhotsk terrane, located east of the South Verkhoyansk sector of the Verkhoyansk fold-and-thrust belt, has Archean crystalline basement and Riphean to Early Paleozoic sedimentary cover similar to that of the adjacent the North Asian craton. However, 2.6 Ga biotite orthogneisses of the Upper Maya uplift of the Okhotsk terrane yielded Early Devonian ${ }^{40} \mathrm{Ar} /{ }^{39} \mathrm{Ar}$ cooling ages, evidence of a MidPaleozoic metamorphic event not previously known. These gneisses are also intruded by $375 \pm 2 \mathrm{Ma}$ (Late Devonian) calc-alkaline granodiorite plutons that we interpret as part of a continental margin volcanic arc. Therefore, Late Devonian rifting, which affected the entire eastern margin of North Asia separating the Okhotsk terrane from the North Asian craton, was probably a back-arc event.

Our limited ${ }^{40} \mathrm{Ar} /{ }^{39} \mathrm{Ar}$ data from the South Verkhoyansk metamorphic belt suggests that low grade metamorphism and deformation started in the Late Jurassic due to accretion of the Okhotsk terrane to the North Asia margin along the Bilyakchan fault. Shortening and ductile strain continued in the core of the South Verkhoyansk metamorphic belt until about 120 Ma due to paleo-Pacific subduction along the UdaMurgal continental margin arc.
\end{abstract}

\section{Introduction}

Northeastern Russia contains a complex array of continental and arc terranes that were accreted to the eastern margin of the North Asian craton since the Late Jurassic (Fig. 1) (e.g. Nokleberg et al., 2000). The accretion process created the Verkhoyansk fold-and-thrust belt by shortening the clastic

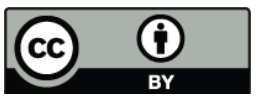

Correspondence to: J. Toro

(jtoro@wvu.edu) wedge that existed along the eastern passive margin of the North Asian craton (Parfenov et al., 1995). However, the history and tectonic affinity of several of the continental terranes east of the Verkhoyansk fold-and-thrust belt is not clear. Geological and paleomagnetic data suggest that they may be fragments of North Asia that were removed by Late Proterozoic or Mid-Paleozoic rifting events and later returned to the margin. One of these fragments that has an Archean nucleus with links to the North Asian craton is the Okhotsk terrane, which is located east of the South Verkhoyansk sector of the Verkhoyansk fold-and-thrust belt (Figs. 1 and 2). In this paper we present new geochronological and geochemical data from the South Verkhoyansk sector and from the Upper Maya uplift of the Okhotsk terrane and use these data to elucidate the geodynamic setting of Pre-Mesozoic magmatism and the timing of metamorphism, deformation, and terrane accretion in the region.

\section{General description of the South Verkhoyansk sector and the Okhotsk terrane}

In the South Verkhoyansk sector, sedimentary rocks ranging from Late Proterozoic to Jurassic were thrust to the west over the North Asian craton. The frontal part of the orogen is a classic thrust belt, known as the Kyllakh zone, with thrust sheets about $5 \mathrm{~km}$ thick composed of Riphean quartzites and carbonates, covered by thinner Early Paleozoic platformal strata (Prokopiev et al., 2001; Toro et al., 2001). Further east, the Early-Middle Paleozoic strata are thicker, represent deeper water facies, and are overlain by a succession of Carboniferous to Jurassic clastic rocks up to $10 \mathrm{~km}$ thick, known as the Verkhoyansk complex. These rocks are penetratively deformed, although the metamorphic grade is generally low. This part of the orogen is

Published by Copernicus Publications on behalf of the European Geosciences Union. 


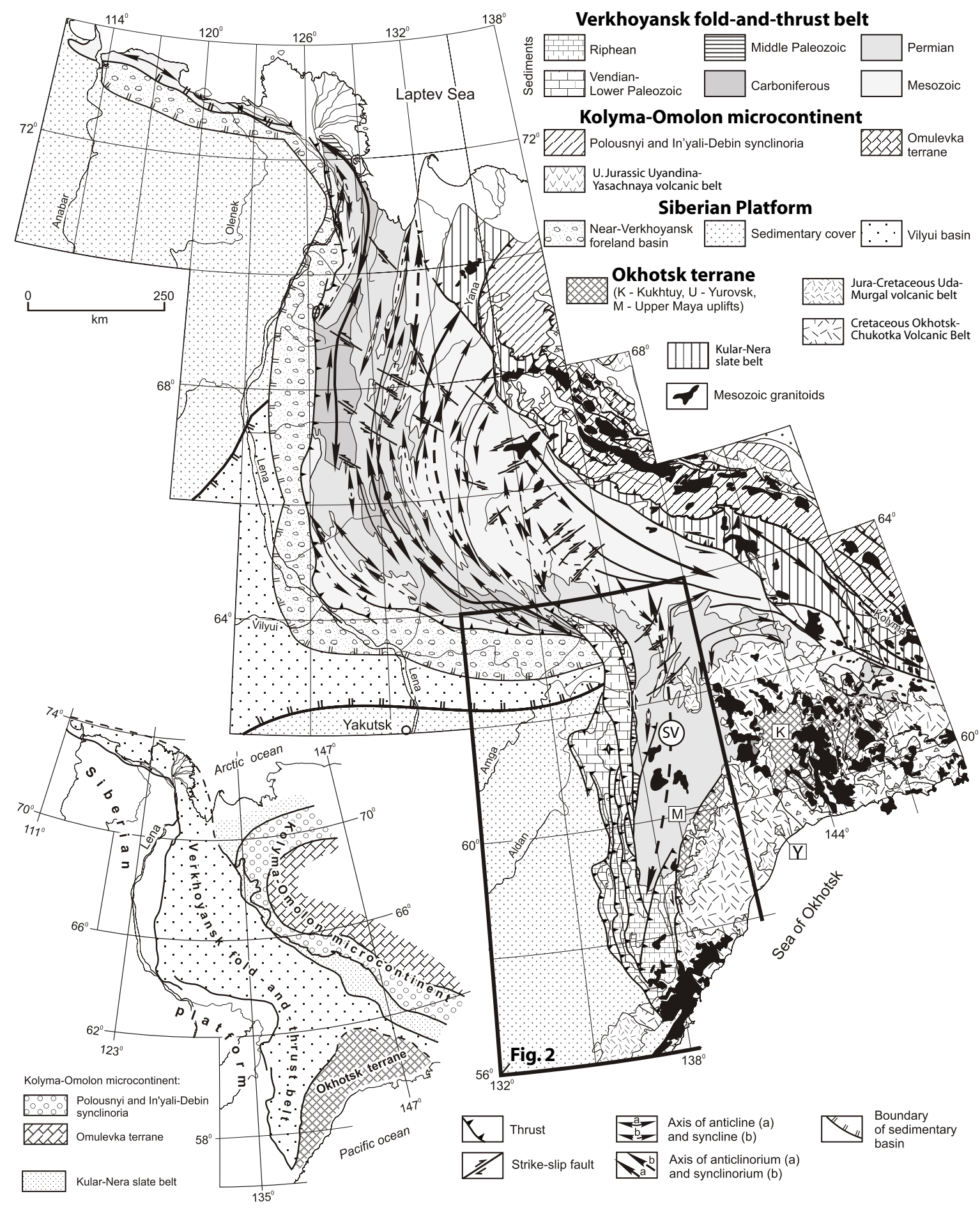

Fig. 1. Regional map of the part of the Verkhoyansk-Kolyma orogen, modified from Parfenov and Kuzmin (2001). Abbreviations : K Kukhtuy uplift, M - Upper Maya uplift, SV - South Verkhoyansk sector, Y - Yurovsk uplift.

mapped as the Sette-Daban tectonic zone. The core of the range, known as the Allakh-Yun' zone, is a doubly-vergent structural fan intruded by a belt of Cretaceous calc-alkaline granitoid plutons. The Uemlyakh batholith, which is the largest of the belt, yielded a U-Pb SHRIMP-RG concordia age of $120.4 \pm 0.6 \mathrm{Ma}$, while the Tarbagannakh batholith was $123 \pm 1 \mathrm{Ma}$. The eastern boundary of the South Verkhoyansk sector is the left-lateral Bilyakchan fault which separates it from the Okhotsk terrane (Fig. 2). 


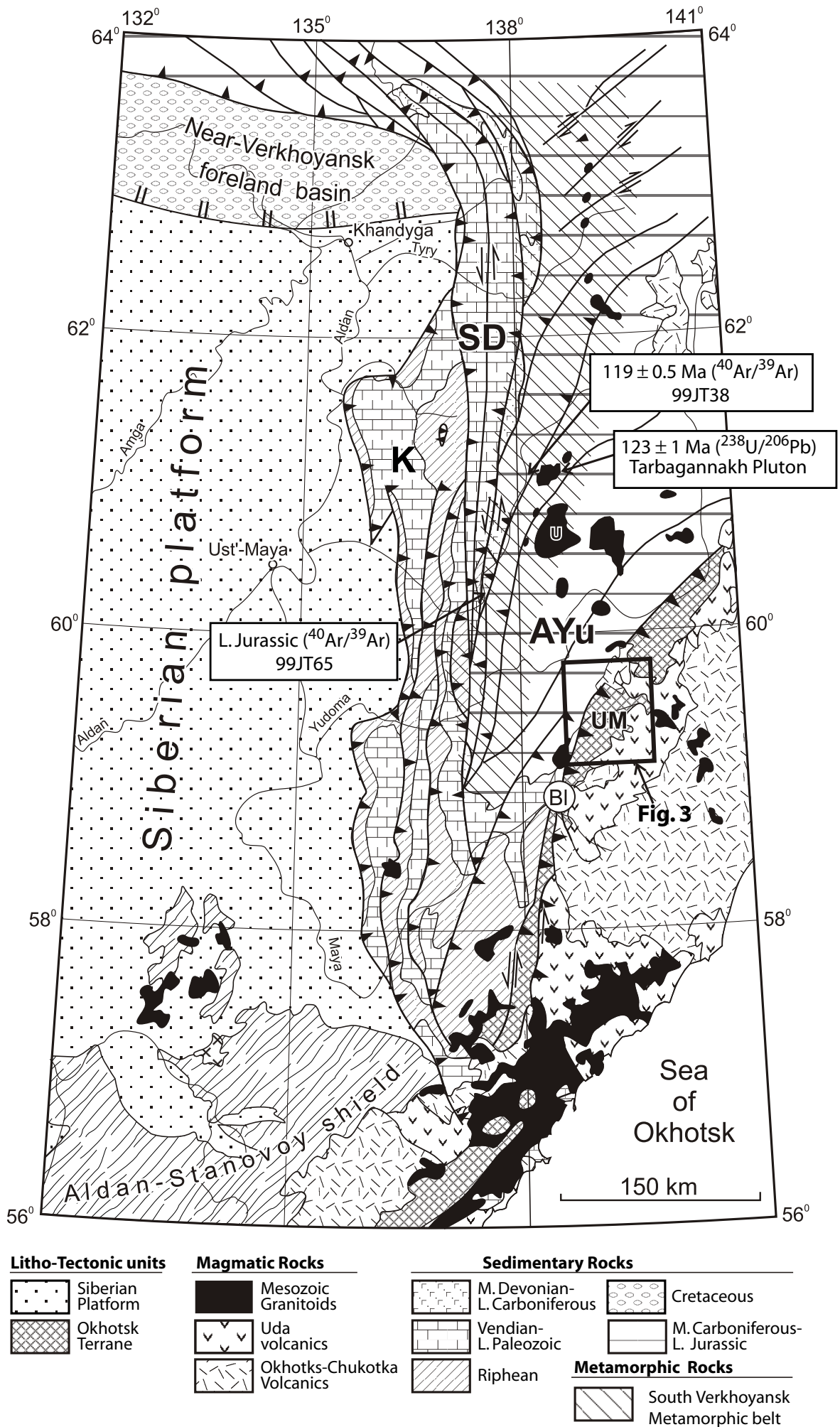

Fig. 2. Structural setting of the South Verkhoyansk sector of the Verkhoyansk fold-and-thrust belt and the Upper Maya uplift. Abbreviations: AYu - Allakh-Yun zone, Bl - Bilyakchan fault, K - Kyllakh zone, SD - Sette-Daban zone, U - Uemlyakh granitoid batholith, UM - Upper Maya uplift. Thrust faults are ornamented with black teeth. 


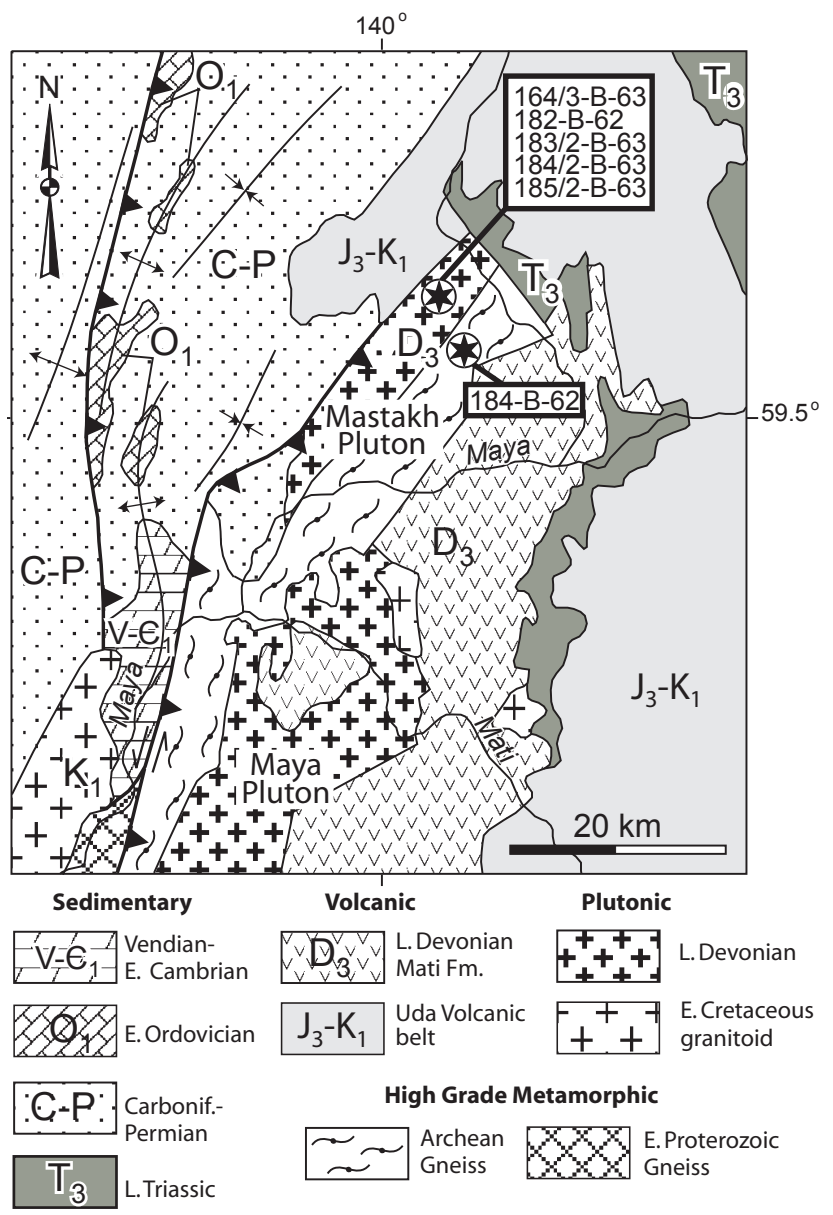

Fig. 3. Geological map of the northern Upper Maya uplift of the Okhotsk terrane modified from Verzhkhovskaya and Krichevets (1982). For location see Fig. 2. Stars represent the sample localities discussed.

Large outcrops of basement rocks in the Okhotsk terrane are found in the Upper Maya uplift, located near its western margin (Fig. 3). These rocks are Archean and Early Proterozoic schists and gneisses of granulite to amphibolite facies metamorphic grade (Grinberg, 1968; Vel'dyaksov and Peskov, 1973; Avchenko, 1975). They include amphibolites, biotite-plagioclase and biotite-amphibole gneisses and schists intruded by alkali granites (Chikov, 1978). Gneisses in the Kukhtuy and Yurovsk uplifts of the Central and Southern Okhotsk terrane (Fig. 1) have yielded $\mathrm{Pb}-\mathrm{Pb}$ zircon ages of 3350 to $1830 \mathrm{Ma}$ (Kuz'min et al., 1995) and 1995 to $1720 \mathrm{Ma}$ (Kuz'min, 1993). K-Ar ages are younger than 2650 Ma (Zagruzina, 1975). No age determinations were previously available from the Upper Maya uplift, but our new data confirm the presence of Paleoproterozoic rocks that had been proposed on the basis of regional correlations (Grinberg, 1968; Kogen et al., 1976; Chikov, 1978).

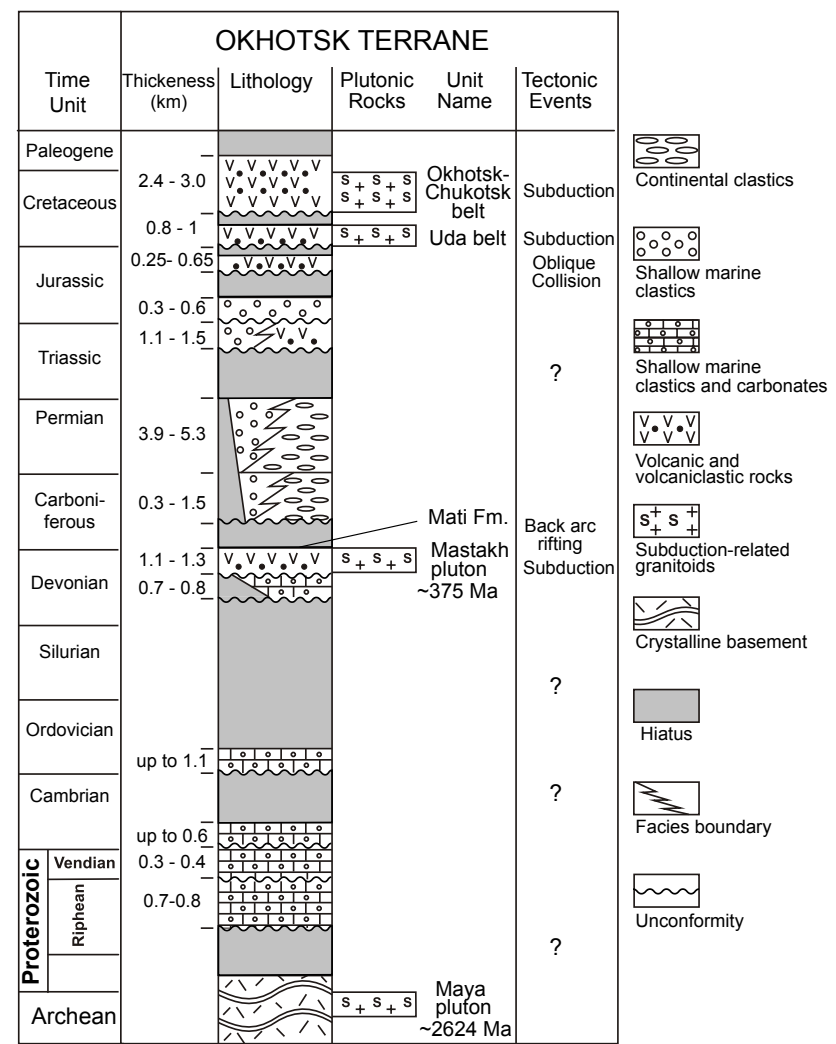

Fig. 4. Stratigraphic column for the Okhotsk terrane. See the text for references.

The high-grade basement rocks of the Okhotsk terrane are overlain by weakly metamorphosed undeformed sedimentary and volcanoclastic deposits of Late Proterozoic to Triassic age that are exposed among fields of Cretaceous arc volcanic rocks and granitoids (Figs. 3 and 4). The oldest units in the sedimentary sequence are Middle to Upper Riphean quartzite, sandstone, siltstone, mudstone, and limestone $(750-850 \mathrm{~m})$. These are unconformably overlain by Vendian siltstone, mudstone, sandstone, and limestone (369-400 m) and Lower Cambrian siltstone, mudstone, limestone, conglomerate, and quartz sandstone (up to $600 \mathrm{~m}$ ) (Komar and Rabotnov, 1976). Thick Lower Ordovician deposits (up to $1100 \mathrm{~m}$ ) include limestone, sandstone, conglomerate, and marl. There are no documented occurrences of Silurian to Lower Devonian rocks in this region. This Late Proterozoic to Early Paleozoic sequence has strong lithologic similarities with coeval units of the North Asian craton exposed in the frontal thrust sheets of the South Verkhoyansk sector and are interpreted as a passive margin continental platform succession.

Upper Devonian (Frasnian to Famenian) volcanic and sedimentary rocks of the Mati Formation are exposed on the southwestern and central part of the Okhotsk terrane. The lower part of the Mati Formation is composed of shallow 
marine carbonate and clastic rocks, while its upper part is rhyolitic to andesitic lavas, tuffs, and volcaniclastic rocks (Umitbaev, 1976; Chikov, 1978). Carboniferous to Upper Triassic rocks $(1100-1500 \mathrm{~m})$ are mostly clastic, but in the south-western part of the terrane there are also calc-alkaline tuffs. The Lower Jurassic deposits (300-600 m) in the Western Okhotsk terrane are mostly sandstone and carbonaceous mudstone, while in the central part of the terrane there are conglomerates with volcanic pebbles. The Upper Jurassic sequence $(250-650 \mathrm{~m}$ ) consists of interbedded clastic and volcaniclastic strata (Sosunov et al., 1982).

Gusev (1979) proposed that the Okhotsk terrane is in fault contact with the South Verkhoyansk clastic wedge along the left-lateral transpressional Bilyakchan fault (Fig. 3). Unfortunately, the area of the Bilyakchan fault is not well studied. For example, the age and kinematics of metamorphic rocks adjacent to the fault are unknown. However, one significant fact is that the lower part of the section in this area contains spilites and cherts (Kogen et al., 1976) of possible oceanic affinity suggesting that a rift basin once separated the Okhotsk terrane from the North Asian margin.

Both the Okhotsk terrane and adjacent South Verkhoyansk sector are overlapped by Late Jurassic-Neocomian calcalkaline volcanic deposits of the Uda belt and Albian-Late Cretaceous bimodal volcanics of the Okhotsk-Chukotka belt. Both of these are continental margin volcanic arcs produced by subduction of Pacific lithosphere under the North Asian margin and its accreted terranes (Parfenov, 1991).

\section{The Upper Maya uplift}

Our new geochemical and geochronologic data were obtained from rocks of the Upper Maya uplift (Figs. 2 and 3). The basement rocks in this area are amphibolites, biotiteplagioclase and biotite-amphibole gneisses, and schists intruded by alkali granites. This complex was previously believed to be Archean-Paleoproterozoic (Grinberg, 1968; Kogen et al., 1976; Chikov, 1978) because similar complexes exposed in the Central and Southern Okhotsk terrane have such ages (Kuz'min et al., 1993, 1995). Up to $1300 \mathrm{~m}$ of volcanoclastic strata of the Mati Formation overlie crystalline basement in the Upper Maya uplift. These include rhyolites, rhyodacites, trachyrhyolites, dacites, and andesites (Tuchkov and Andrianova, 1972). Although it was initially believed to be younger (Tuchkov and Andrianova, 1972; Korostelev, 1987), the Mati Formation is now assigned a Late Devonian age because is has yielded K-Ar ages as old as $377 \mathrm{Ma}$ (Martynyuk et al., 1990). The Mati Formation is overlain by Triassic (Norian) tuffs 400 to $750 \mathrm{~m}$ thick (Korostelev, 1987; Tuchkov and Andrianova, 1972).

\subsection{Upper Maya biotite orthogneiss}

\subsection{1 $\mathrm{U} / \mathrm{Pb}$ geochronology}

To resolve the age of the crystalline basement of the Upper Maya uplift, we extracted zircons from a biotite orthogneiss (sample 184-B-62). The zircons are 120-150 microns long with an aspect ratio of 1:2.2 and slightly rounded edges, perhaps as a result of resorption during metamorphism. They have normal oscillatory zoning without obvious xenocrystic cores (Fig. 5a). The zircons were analyzed for $\mathrm{U} / \mathrm{Pb}$ isotopic ages using two methods: first 10 zircons were dated with the sensitive high resolution ion microprobe-reverse geometry (SHRIMP-RG) at the USGS-Stanford Microanalytical Center, later 3 single grains and a multi-grain fraction were analyzed by thermal ionization mass-spectrometry (TIMS) at the laboratory of James Mattinson at the University of California - Santa Barbara. The analytical results can be found on Tables 1 and 2 and plotted as a concordia diagram on Fig. 5b using Isoplot software (Ludwing, 2003).

The SHRIMP-RG analytical procedure used is similar to that described in Katkov et al. (submitted, this volume), although the age standard we used was Duluth Gabbro zircon AS-57 with a TIMS age of $1099.1 \mathrm{Ma}$ (Paces and Miller, 1993). The data were corrected for common $\mathrm{Pb}$ using the ${ }^{204} \mathrm{~Pb}$ measured and assuming a $\mathrm{Pb}$ isotopic composition according to the Cumming and Richards (1975) $\mathrm{Pb}$ evolution model. The ten zircons probed had low U content (44$160 \mathrm{ppm}$ ), allowing for low radiation damage of such ancient crystals and very precise age determinations. For Proterozoic and older rocks, ${ }^{207} \mathrm{~Pb} /{ }^{206} \mathrm{~Pb}$ SHRIMP ages are the most reliable (Ireland and Williams, 2003) so we report these on Table 1. Apparent ages range from $2539 \pm 17$ to $2670 \pm 20 \mathrm{Ma}$. We interpret the scatter of ages and slight discordance as a result of $\mathrm{Pb}$ loss, and exclude the two youngest ages from the calculation of the weighted mean age of $2624 \pm 12 \mathrm{Ma}$ (Fig. 5b).

The precision of TIMS data allows us to better document the degree of discordance of the U-Pb isotopic system. The four fractions analyzed spread along a cord in the Wetherill concordia diagram with an upper intercept of $2595 \pm 26 \mathrm{Ma}$ (Table 2 and Fig. 5b). This age overlaps within the analytical uncertainty the weighted mean of ${ }^{207} \mathrm{~Pb} /{ }^{206} \mathrm{~Pb}$ ages determined on the SHRIMP-RG, and provides a good approximation to the crystallization age of the granitoid protolith of the Upper Maya biotite gneiss. This Neoarchean age is similar to the ages of plagiogneiss, enderbite, and charnockite from the hornblende granulite complex of the Kukhtuy uplift of the central part of the Okhotsk terrane (Kuz'min et al., 1995). The lower intercept with concordia, which may represent the time of $\mathrm{Pb}$-loss from the zircons, is poorly constrained at $597 \pm 780 \mathrm{Ma}$. The best candidate for this event was Devonian metamorphism documented by our ${ }^{40} \mathrm{Ar} /{ }^{39} \mathrm{Ar}$ geochronology discussed below. 
Table 1. U-Pb SHRIMP-RG data from the Upper Maya biotite orthogneiss. Sample Location: $59.5566^{\circ} \mathrm{N}$ lat., $140.072^{\circ} \mathrm{E}$ long.

\begin{tabular}{|c|c|c|c|c|c|c|c|c|c|}
\hline \multirow{3}{*}{ Spot } & \multirow{3}{*}{$\begin{array}{l}\%^{206} \mathrm{~Pb} \\
\text { comm }\end{array}$} & \multirow{3}{*}{$\begin{array}{l}{ }^{206} \mathrm{~Pb}^{*} \\
\mathrm{ppm}\end{array}$} & \multirow{3}{*}{$\begin{array}{l}\mathrm{U} \\
\mathrm{ppm}\end{array}$} & \multirow{3}{*}{$\begin{array}{l}\text { Th } \\
\text { ppm }\end{array}$} & \multirow{3}{*}{$\mathrm{Th} / \mathrm{U}$} & \multicolumn{4}{|c|}{${ }^{204} \mathrm{~Pb}-$ Corrected } \\
\hline & & & & & & ${ }^{207} \mathrm{~Pb} /{ }^{235} \mathrm{U}$ & ${ }^{206} \mathrm{U} /{ }^{238} \mathrm{~Pb}$ & ${ }^{207} \mathrm{~Pb} /{ }^{206} \mathrm{~Pb}$ & ${ }^{207} \mathrm{~Pb} /{ }^{206} \mathrm{~Pb}$ \\
\hline & & & & & & & & & Age (Ma) \\
\hline 184-B-63-1 & 0.09 & 54 & 124 & 101 & 0.84 & $11.70 \pm 0.16$ & $0.5048 \pm 0.0048$ & $0.1681 \pm 0.0017$ & $2539 \pm 17^{1}$ \\
\hline 184-B-63-2 & 0.15 & 66 & 160 & 132 & 0.86 & $11.15 \pm 0.15$ & $0.4795 \pm 0.0043$ & $0.1686 \pm 0.0017$ & $2544 \pm 17^{1}$ \\
\hline 184-B-63-3 & 0.00 & 30 & 68 & 28 & 0.43 & $12.74 \pm 0.20$ & $0.5132 \pm 0.0056$ & $0.1800 \pm 0.0021$ & $2653 \pm 19$ \\
\hline 184-B-63-4 & 0.15 & 33 & 75 & 32 & 0.44 & $12.76 \pm 0.21$ & $0.5087 \pm 0.0054$ & $0.1819 \pm 0.0022$ & $2670 \pm 20$ \\
\hline 184-B-63-5 & 0.00 & 52 & 120 & 75 & 0.64 & $12.14 \pm 0.16$ & $0.5032 \pm 0.0046$ & $0.1750 \pm 0.0017$ & $2606 \pm 17$ \\
\hline 184-B-63-6 & 0.00 & 36 & 87 & 65 & 0.77 & $11.89 \pm 0.19$ & $0.4858 \pm 0.0051$ & $0.1775 \pm 0.0021$ & $2629 \pm 20$ \\
\hline 184-B-63-7 & 0.90 & 17 & 44 & 29 & 0.67 & $10.59 \pm 0.35$ & $0.4544 \pm 0.0068$ & $0.1690 \pm 0.0049$ & $2548 \pm 49$ \\
\hline 184-B-63-8 & 0.10 & 47 & 109 & 65 & 0.61 & $12.32 \pm 0.18$ & $0.5039 \pm 0.0050$ & $0.1773 \pm 0.0019$ & $2628 \pm 18$ \\
\hline 184-B-63-9 & 0.05 & 51 & 114 & 68 & 0.62 & $12.60 \pm 0.17$ & $0.5175 \pm 0.0048$ & $0.1766 \pm 0.0017$ & $2621 \pm 16$ \\
\hline \multirow[t]{2}{*}{ 184-B-63-10 } & 0.07 & 64 & 148 & 90 & 0.63 & $12.24 \pm 0.14$ & $0.5069 \pm 0.0040$ & $0.1752 \pm 0.0014$ & $2607 \pm 14$ \\
\hline & & & & & \multicolumn{4}{|c|}{ Weighted Mean ${ }^{204} \mathrm{~Pb}$ corrected ${ }^{207} \mathrm{~Pb} /{ }^{206} \mathrm{~Pb}$ Age $(2 \sigma)$ : } & $\mathrm{MSWD}=1.85, \mathrm{n}=8 / 10$ \\
\hline
\end{tabular}

$\mathrm{Pb}^{*}$ is radiogenic $\mathrm{Pb} .{ }^{1}$ Excluded from the calculation of the weighted mean. MSWD is the Mean Standard Weighted Deviation.

Table 2. U-Pb TIMS data from the Upper Maya biotite orthogneiss.

\begin{tabular}{|c|c|c|c|c|c|c|c|c|c|c|c|c|}
\hline \multirow[b]{2}{*}{ Sample } & \multirow[b]{2}{*}{ \# grains } & \multirow[b]{2}{*}{$\mathrm{Th} / \mathrm{U}$} & \multirow[b]{2}{*}{$\begin{array}{l}{ }^{1} \mathrm{~Pb}^{*} \\
\mathrm{ng}\end{array}$} & \multirow[b]{2}{*}{$\begin{array}{l}\mathrm{Pb}_{c} \\
\mathrm{pg}\end{array}$} & \multicolumn{5}{|c|}{ Isotopic Ratios $^{2}$} & \multicolumn{3}{|c|}{ Apparent Ages } \\
\hline & & & & & ${ }^{206} \mathrm{~Pb} /{ }^{204} \mathrm{~Pb}$ & ${ }^{208} \mathrm{~Pb} /{ }^{206} \mathrm{~Pb}$ & ${ }^{206} \mathrm{~Pb}^{*}{ }^{38} \mathrm{U}$ & ${ }^{207} \mathrm{~Pb}^{*} /{ }^{235} \mathrm{U}$ & ${ }^{207} \mathrm{~Pb}^{*} / 206 \mathrm{~Pb}^{*}$ & ${ }^{206} \mathrm{~Pb} /{ }^{238} \mathrm{U}$ & ${ }^{207} \mathrm{~Pb} /{ }^{235} \mathrm{U}$ & ${ }^{207} \mathrm{~Pb} /{ }^{206} \mathrm{~Pb}$ \\
\hline 184-B-63a & 4 & 0.51 & 0.82 & 4.9 & 12602 & 0.14100 & 0.49682 & 11.83961 & 0.17284 & $2600 \pm 52$ & $2592 \pm 52$ & $2585 \pm 2$ \\
\hline 184-B-63b & 1 & 0.67 & 0.29 & 5.0 & 4266 & 0.19180 & 0.46341 & 10.94512 & 0.17130 & $2455 \pm 49$ & $2518 \pm 50$ & $2570 \pm 4$ \\
\hline $184-B-63 c$ & 1 & 0.67 & 0.18 & 71.4 & 192 & 0.19316 & 0.45691 & 10.80911 & 0.17158 & $2426 \pm 48$ & $2507 \pm 50$ & $2573 \pm 17$ \\
\hline $184-B-63 d$ & 1 & 0.77 & 0.21 & 8.0 & 1997 & 0.17501 & 0.48244 & 11.60868 & 0.17452 & $2538 \pm 51$ & $2573 \pm 51$ & $2601 \pm 7$ \\
\hline
\end{tabular}

${ }^{1} \mathrm{~Pb}^{*}$ is radiogenic $\mathrm{Pb}$.

${ }^{2}$ Reported ratios corrected for fractionation ( $\left.0.125 \pm 0.038 \% / \mathrm{AMU}\right)$ and spike $\mathrm{Pb}$. Ratios used in age calculation were adjusted for $5 \mathrm{pg}$ of blank $\mathrm{Pb}$ with isotopic composition of ${ }^{206} \mathrm{~Pb} /{ }^{204} \mathrm{~Pb}=18.6,{ }^{207} \mathrm{~Pb} /{ }^{204} \mathrm{~Pb}=15.5$, and ${ }^{208} \mathrm{~Pb} /{ }^{204} \mathrm{~Pb}=38.4,2$ pg of blank $\mathrm{U}, 0.25 \pm 0.049 \% / \mathrm{AMU}$ fractionation for $\mathrm{UO}_{2}$, and initial common $\mathrm{Pb}$ with isotopic composition approximated from Cumming and Richards (1975) and assigned uncertainty of 0.1 to initial ${ }^{207} \mathrm{~Pb} /{ }^{204} \mathrm{~Pb}$.

${ }^{3}$ Uncertainties reported as $2 \sigma$. Decay constants: ${ }^{238} \mathrm{U}=1.5513 \mathrm{E}-10,{ }^{235} \mathrm{U}=9.8485 \mathrm{E}-10 ;{ }^{238} \mathrm{U} /{ }^{235} \mathrm{U}=137.88$.

\subsection{2 ${ }^{40} \mathrm{Ar} /{ }^{39} \mathrm{Ar}$ geochronology}

We analyzed a pure biotite separate from the Upper Maya orthogneiss at the ${ }^{40} \mathrm{Ar} /{ }^{39} \mathrm{Ar}$ laboratory of Stanford University using progressive step heating with a resistance furnace. The analytical procedures used were similar to those described by Hacker et al. (1996). A summary of the ${ }^{40} \mathrm{Ar} /{ }^{39} \mathrm{Ar}$ results is shown on Table 3 and the full analytical data can be found in the data repository. During the stepwise heating experiment (Fig. 6) ages climbed from as young as $74 \mathrm{Ma}$ at the lowest temperature to, $411 \mathrm{Ma}$ at $1000^{\circ} \mathrm{C}$. Above this temperature the release spectrum is a relatively flat pseudo-plateau encompassing $98.9 \%$ of the radiogenic ${ }^{39} \mathrm{Ar}$ released, with a weighted mean age of $416 \pm 5 \mathrm{Ma}$. The inverse isochron age is concordant with this age, although the ${ }^{40} \mathrm{Ar} /{ }^{36} \mathrm{Ar}$ intercept is poorly constrained making it difficult to verify whether the sample contained excess Ar. The overall pattern of the spectrum suggests that cooling below the closure temperature of biotite $\left(\sim 300^{\circ} \mathrm{C}\right)$ occurred at about $416 \mathrm{Ma}$ (Earliest Devonian) and was followed by partial loss of Ar due to a younger heating event. We interpret this data as evidence for Early Devonian regional metamorphism in the Upper Maya uplift.

\subsubsection{U-Th/He Geochronology}

Two inclusion-free zircon grains were selected for $\mathrm{U}-\mathrm{Th} / \mathrm{He}$ dating in order to evaluate the exhumation history of the Upper Maya orthogneiss. The $\mathrm{U}-\mathrm{Th} / \mathrm{He}$ system is a lowtemperature thermochronometer which dates the time of cooling to below the temperature at which $\mathrm{He}$ is no longer able to escape from the crystal lattice by diffusion over a geological time scale. For zircon, this closure temperature is about $180^{\circ} \mathrm{C}$ (Reiners, 2005). The analyses were carried 
Table 3. Summary of 40Ar/39Ar Date from the South Verkhoyansk and Upper May Uplift.

\begin{tabular}{|c|c|c|c|c|c|c|c|c|c|c|c|}
\hline Sample & Lithology & Rock Age & Mineral & $\begin{array}{l}\text { Lat. } \\
\mathrm{N}\end{array}$ & $\begin{array}{l}\text { Long. } \\
\text { E }\end{array}$ & $\begin{array}{l}\text { Total Fusion } \\
\text { Age, Ma }\end{array}$ & $\begin{array}{l}\text { Isochron } \\
\text { Age, Ma }\end{array}$ & MSWD & ${ }^{40} \mathrm{Ar} /{ }^{36} \mathrm{Ar}$ & $\begin{array}{l}\text { Weighed Mean } \\
\text { Age, Ma }\end{array}$ & $\begin{array}{l}\%^{39} \mathrm{Ar} \\
\text { Used }\end{array}$ \\
\hline 184-B-62 & Biotite Gneiss & $2.6 \mathrm{Ga}$ & Siotite & 59.5566 & 140.072 & $398 \pm 3$ & $418 \pm 6$ & 0.004 & $707 \pm 1300$ & $415 \pm 5$ & 90 \\
\hline 182-B-63 & Granodiorite & $375.3 \pm 2.3$ & Biotite & 59.6008 & 140.084 & $346 \pm 3$ & $356 \pm 6$ & 0.06 & $279 \pm 1700$ & $355.2 \pm 1$ & 66 \\
\hline 99-JT-38 & Bio Quartzite & Carboniferous & Biotite & 61.1109 & 138.2432 & $118.2 \pm 0.5$ & $120.3 \pm 0.7$ & 5.35 & $147 \pm 52$ & $119.4 \pm 0.5$ & 96 \\
\hline 99-JT-65 & Mus Marble & Ordovician & Muscovite & 60.1311 & 137.2225 & $135.8 \pm 2.6$ & $160.4 \pm 6.7$ & 10.6 & $1736 \pm 1608$ & NA & \\
\hline
\end{tabular}

MSWD is the mean square weighted deviation, a measure of the goodness of fit of the isochron. The following is a summary of key laboratory procedures. Clean 1-5 mg of each mineral sample were packaged in Al foil and irradiated at the TRIGA reactor at the University of Oregon. The analyses were done at the laboratory of M. McWilliams at Stanford University using procedures described by Hacker et al. (1996). The mass-spectrometer data were corrected for neutron flux gradient using the sanidine standard 85G003 with assumed age of $27.92 \mathrm{Ma}$. All the analyses were corrected for decay since irradiation, mass discrimination, and interference of Cl-, Ca-, and $\mathrm{K}$-produced $\mathrm{Ar}$ isotopes. Uncertainties reported are one sigma, determined using the uncertainties in: monitor age, decay rates of ${ }^{37} \mathrm{Ar}$, ${ }^{39} \mathrm{Ar}$, and ${ }^{40} \mathrm{Ar}$, rates of reactor produced Ar-isotopes, duration of irradiation, time since irradiation, peak heights, blank values, and irradiation parameter $J$.

Table 4. (U-Th)/He data from zircons of the Upper Maya Orthogneiss.

\begin{tabular}{llllllll}
\hline Sample & \# grains & $\mathrm{U}(\mathrm{ng})$ & $\mathrm{Th}(\mathrm{ng})$ & ${ }^{4} \mathrm{He}(\mathrm{pmol})$ & $F_{T}$ & $(\mathrm{U}-\mathrm{Th}) /$ He Age $(\mathrm{Ma})$ & Corrected Age (Ma) \\
\hline 184-B-63a & 1 & 0.692 & 0.477 & 0.853 & 0.823 & $194 \pm 15$ & $235 \pm 19$ \\
184-B-63b & 1 & 0.405 & 0.279 & 0.557 & 0.843 & $211 \pm 17$ & $251 \pm 20$ \\
\hline & & & & Weighted Mean Age & $244 \pm 33$ \\
\hline
\end{tabular}

$F_{T}$ is the alpha ejection correction factor (Hourigan et al., 2005). Corrected Age is the (U-Th)/He age corrected for alpha ejection.

out at the Yale University (U-Th)/He Chronometry Lab using methods similar to those described by Flowers et al. (2006). After correcting for alpha ejection (Table 4), the zircon $\mathrm{He}$ ages of the two grains are $235 \pm 19$ and $251 \pm 20 \mathrm{Ma}$, for a weighted mean age of $242 \pm 33 \mathrm{Ma}$ (Middle Triassic). Although this is a very small data set, this result is significant because it demonstrates that the high grade gneisses of the Upper Maya had been exhumed to within a few kilometers of the surface by Middle Triassic time, and were not significantly reheated at a younger date.

\subsection{Mastakh granitoid pluton}

\subsubsection{Petrography and geochemistry}

This pluton is located north of the Maya river within the Upper Maya uplift where it intrudes into the Neoarchean gneisses discussed above, and is overlain by the Middle Carboniferous rocks (Fig. 3) (Martynyuk et al., 1990). The pluton is composed of medium- to coarse-grained, often porphyritic biotite-amphibole granodiorite mingled with quartz diorite. It contains plagioclase $\left(\mathrm{An}_{25--35}\right)$ and medium- to high-ordered $\mathrm{Na}-\mathrm{K}$ feldspars. The main mafic minerals are biotite (8-9\%) and hornblende (8-16\%). Accessory minerals include magnetite, titanite, allanite, and epidote. Zircon and apatite are present in trace amounts. Anatase and xenotime occur as solitary grains.
Granitoids of the Mastakh pluton have a calc-alkaline composition (Fig. 7a). Alkalies in the granodiorites are 7.92$8.22 \%$ with $\mathrm{K}_{2} \mathrm{O}$ prevailing over $\mathrm{Na}_{2} \mathrm{O}$. In quartz diorites, alkalies are $5.87-7.04 \%$, and $\mathrm{Na}_{2} \mathrm{O}$ prevails over $\mathrm{K}_{2} \mathrm{O}$. The granitoids show wide ranges of $f(55-68)$ and $\mathrm{K}_{a}(0.48$ 0.68). They are metaluminous rocks (Fig. 7b) with ASI indeces varying from 0.86 to 0.95 , which suggests that they are I-type granites. Based on ICP trace element analyses of 4 samples (Fig. 7), we see that they have high Ba (680$1060 \mathrm{ppm})$ and low $\mathrm{Rb}(36-77 \mathrm{ppm})$, Th (3.33-7.85 ppm), $\mathrm{U}$ (0.55-1.64 ppm), Ta (0.65-1.52 ppm), Zr (11-47 ppm), $\mathrm{Nb}$ (8.03-18.13 ppm), Hf (0.79-2.55 ppm), P (785-1527), Ti (2817-4496) and $\Sigma$ REE (146-193 ppm). REE have fractionated distribution spectra with a high (8.98-18.04) $(\mathrm{La} / \mathrm{Yb})_{n}$ ratio. LREE are more fractionated than HREE $\left.\left((\mathrm{La} / \mathrm{Sm})_{n}=2.99-5.6 ; \quad(\mathrm{Gd} / \mathrm{Yb})_{n}=1.99-2.43\right)\right)$. No distinct negative Eu anomaly is observed (Fig. 7c). The chondritenormalized REE pattern is very similar to an average of 172 representative granitoids from the Sierra Nevada of California extracted from the Western North America Intrusive and Volcanic Rocks Database (NAVDAT, 2007). In general, the granitoids of the Mastakh pluton are comparable to subduction-related continental-margin tonalite-granodiorite plutons of western North America and the Urals (Fershtater, 2001) in their mineralogical composition, REE distribution and the presence of well-defined $\mathrm{Ta}, \mathrm{Nb}, \mathrm{Zr}$, and $\mathrm{Ti}$ negative anomalies (Fig. 7d). However, the rocks of the Mastakh 

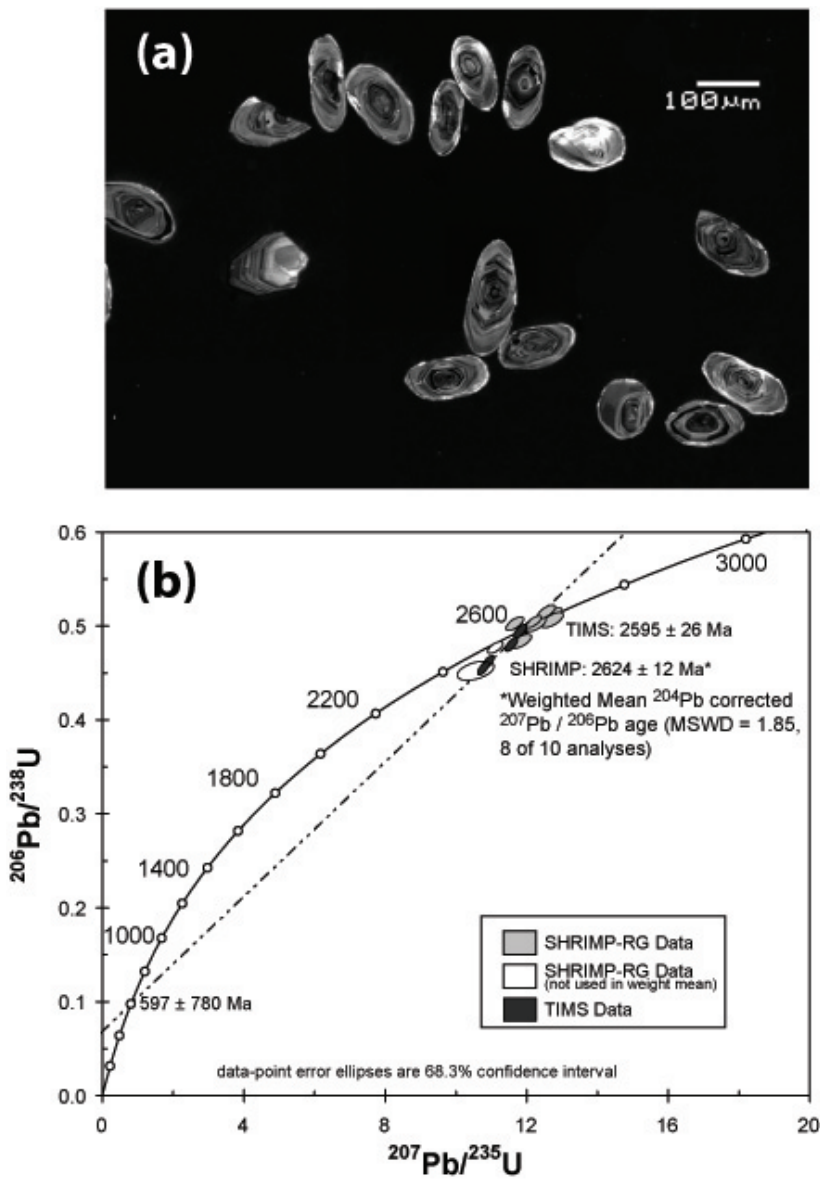

Fig. 5. $\mathrm{U} / \mathrm{Pb}$ zircon data from the Upper Maya biotite orthogneiss, sample 184-B-62. (a) Cathodoluminecense image of zircons acquired with a JEOL JSM 5600 scanning electron microscope. (b) Wetherill concordia diagram showing both SHRIMP-RG and TIMS data. The slight discordance documented by the TIMS ages suggests $\mathrm{Pb}$-loss during a Late Proterozoic to Phanerozoic metamorphic event. The upper intercept of the TIMS ages and the weighted mean of the SHRIMP ages over lap within the uncertainty. We interpret the crystallization age of the orthogneiss protolith as approximately $2.6 \mathrm{Ga}$.

pluton have considerably lower $\mathrm{U}$, Th, and $\mathrm{Zr}$ than their Sierra Nevada counterparts. In the discrimination diagrams of Pearce et al. (1984) the Upper Maya plutonic rocks plot into the field of volcanic arc granites (Fig. 8).

\subsubsection{Geochronology}

There is no consensus in the literature as to the age of the plutons of the Upper Maya granitoids. According to (Tuchkov and Andrianova, 1972), the Mastakh and Maya plutons intrude into the rocks of the Late Devonian Mati Formation causing contact metamorphism, but they do not have a thermal effect on the Upper Triassic rocks. However, poor outcrop conditions in the area left room for other interpretations.
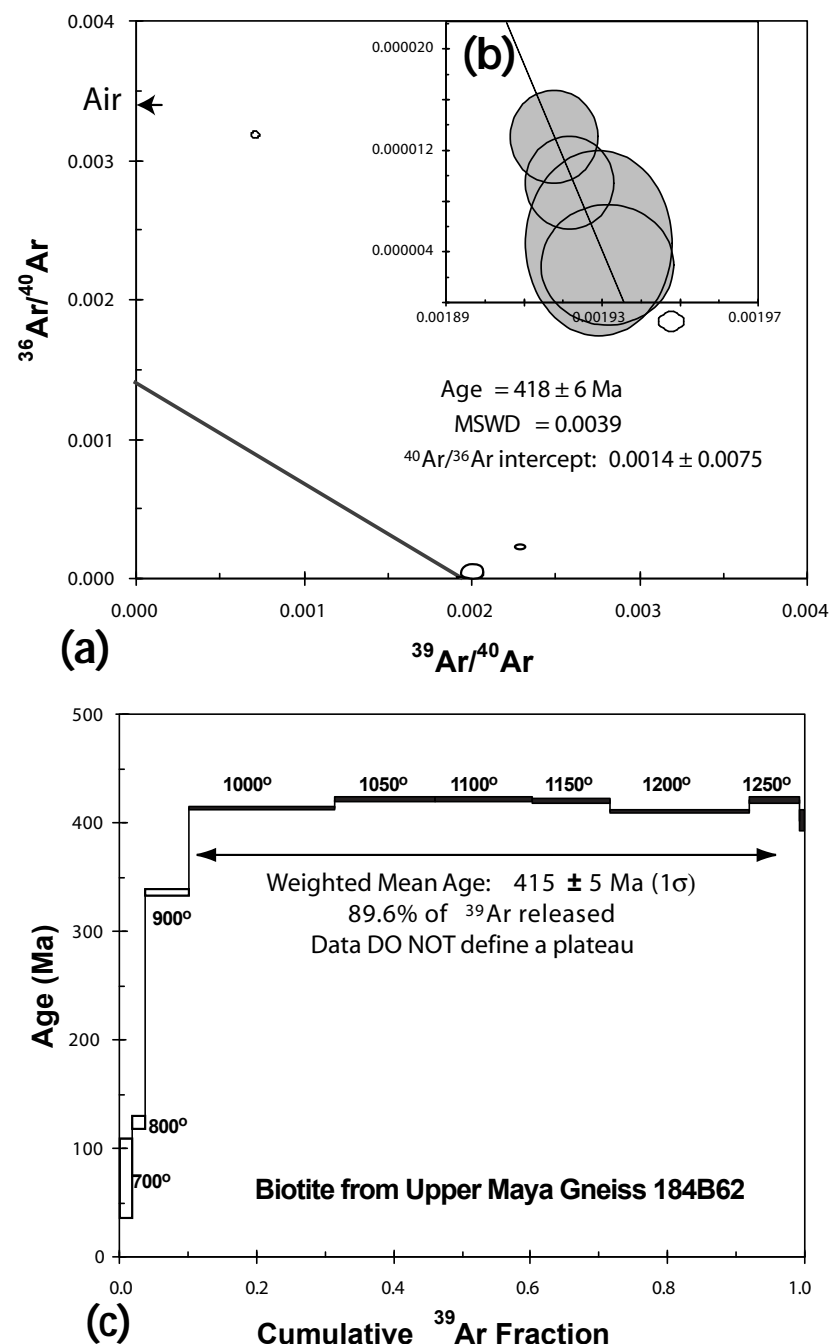

Fig. 6. ${ }^{40} \mathrm{Ar} /{ }^{39} \mathrm{Ar}$ data from biotite sample of the Upper Maya Archean orthoneiss sample 184-B-62. (a) Inverse isochron plot calculated using the steps highlighted in black in the spectrum. The ${ }^{36} \mathrm{Ar} /{ }^{40} \mathrm{Ar}$ intercept is poorly constrained, but overlaps within the uncertainty with the expected atmospheric ratio (air). (b) Enlargement of the intercept with the radiogenic axis of the isochron plot. (c) ${ }^{39} \mathrm{Ar}$ release spectrum. The weighted mean age of $415 \pm 2 \mathrm{Ma}$ overlaps within uncertainty with the isochron age. The three initial steps suggest partial resetting due to a younger thermal event.

The plutons are shown on some geologic maps as Archean (Verzhkhovskaya and Krichevets, 1982) or Early Proterozoic (Gorodinsky, 1980). The available K-Ar ages range from 283 to 573 Ma (Korostelev, 1987; Martynyuk et al., 1990; Nenashev and Zaitsev, 1980). Kuzmin et al. (2003) report a $464 \mathrm{Ma}$ (Late Ordovician) Sm-Nd age for granitoids of the Maya pluton which is difficult to interpret.

To better constrain the age of the Mastakh pluton, we analyzed zircons for $\mathrm{U}-\mathrm{Pb}$ isotopic age from a granodiorite sample (182-B-62) using the SHRIMP-RG and the same 
analytical procedure described above. The zircons are euhedral with aspect ratios of about 2:1 and lengths of 90 to $200 \mu \mathrm{m}$. They display normal magmatic oscillatory zoning in the CL image without obvious xenocrystic cores (Fig. 9a). U concentrations were low for all the spots analyzed (37 to $143 \mathrm{ppm}$, Table 5), although some grains have thin rims that appear very dark under CL, an indication of higher U concentration. The data were corrected for common $\mathrm{Pb}$ using the ${ }^{207} \mathrm{~Pb}$ measured and assuming a $\mathrm{Pb}$ isotopic composition according to Cumming and Richards (1975). The sample yielded a Tera-Wasserburg concordia age of $375.3 \pm 2.3 \mathrm{Ma}$ calculated with Isoplot (Ludwig, 2003) excluding one discordant spot (Fig. 9b). This Late Devonian age demonstrates that the Mastakh pluton and probably also the Maya pluton are coeval with the volcanic rocks of the Mati Formation.

$\mathrm{A}^{40} \mathrm{Ar} /{ }^{39} \mathrm{Ar}$ analysis of biotite from the Mastakh granodiorite produced a ${ }^{39} \mathrm{Ar}$ release spectrum with a reliable plateau age of $355.2 \pm 1.0 \mathrm{Ma}$ representing $63 \%$ of the ${ }^{39} \mathrm{Ar}$ released (Fig. 10a and Table 3). This is concordant with the isochron age that includes all the steps in the experiment, although the ${ }^{40} \mathrm{Ar} /{ }^{36} \mathrm{Ar}$ intercept is poorly constrained. Therefore, the Mastakh pluton cooled below the Ar closure temperature of biotite $\left(\sim 300^{\circ} \mathrm{C}\right.$, McDougall and Harrison, 1988) in the Early Carboniferous, about 20 million years after its emplacement.

\section{Metamorphism in the South Verkhoyansk metamorphic belt}

The South Verkhoyansk metamorphic belt extends in a band $50 \mathrm{~km}$ wide for $600 \mathrm{~km}$ along the eastern flank of the SetteDaban and western flank of the Allakh-Yun' tectonic zones of the South Verkhoyansk sector (Andriyanov, 1973a, b; Nemenman, 1991; Simanovich and Andriyanov, 1984; Sagir, 2001) (see Fig. 2). In its central part (20-25 km wide and $150 \mathrm{~km}$ long) the rocks are metamorphosed to the biotite grade and, locally, to staurolite grade. Metamorphism gradually decreases away from this band. The rocks are isoclinally folded with cleavage striking north-northeast and dipping steeply to the east on the western flank and to the west on the eastern flank creating a bi-vergent fan. Preserved bedding is often at a low angle to the cleavage (Prokopiev, 1989). In the Lower to Middle Paleozoic terrigenous and carbonate rocks of the eastern flank of the Sette-Daban zone, metamorphism led to the formation of marble and the almost complete disappearance of primary structures in the carbonate rocks. The rocks include marbled dolomites and limestones, as well as sericite (muscovite)-chlorite, actinolitechlorite, epidote-actinolite-chlorite and carbonate-sericitechlorite-quartz-albite schists.

In the central part of the Sette Daban zone (Fig. 2), a sample (99 JT 65, Table 3) was taken from Lower Ordovician schistose marble, from which fine muscovite, newly formed on the cleavage surfaces, was extracted. ${ }^{40} \mathrm{Ar} /{ }^{39} \mathrm{Ar}$ isotope
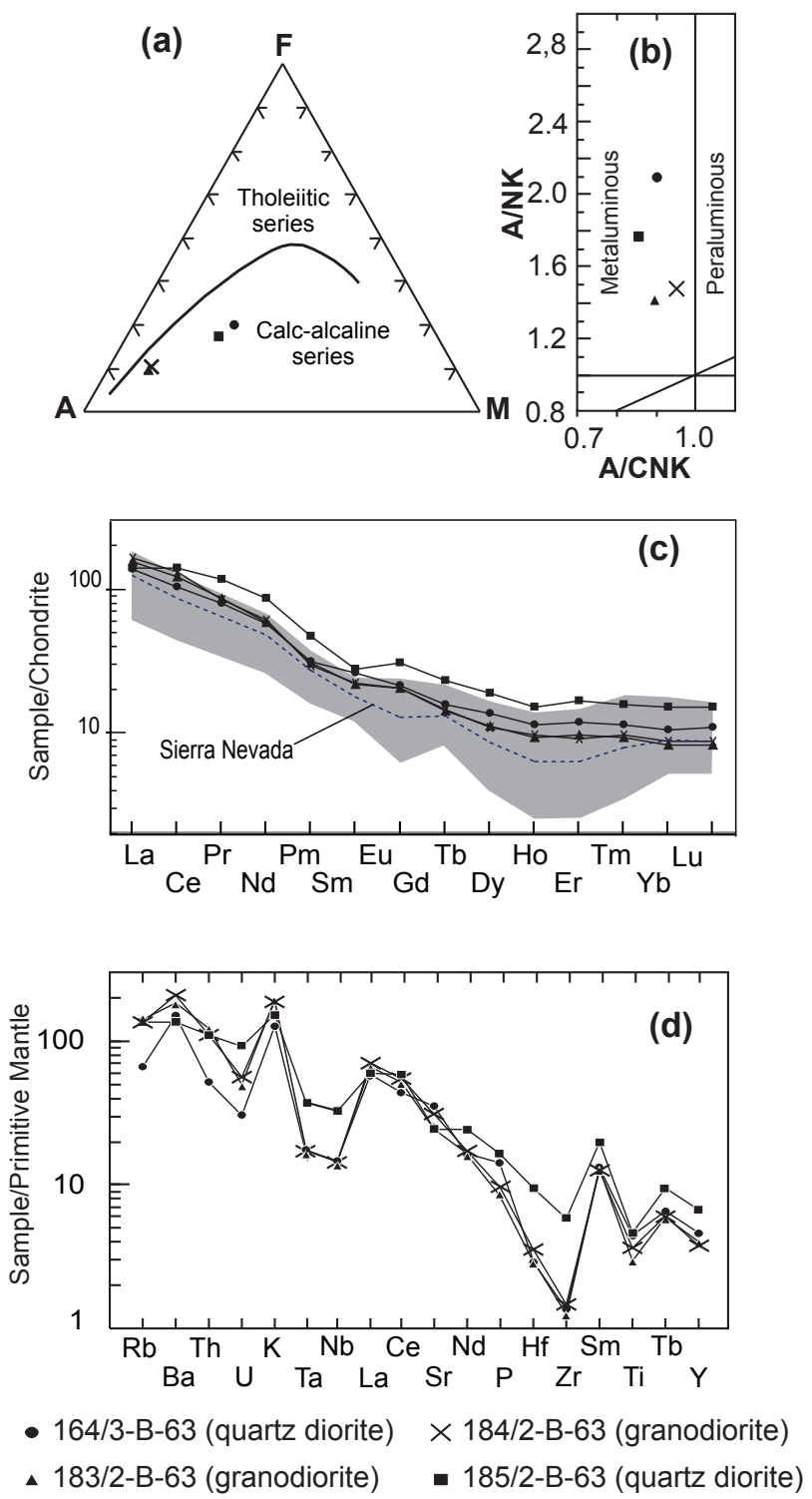

Fig. 7. Geochemical data for four samples of the Mastakh pluton: (a) AFM diagram $\left(\mathrm{A}=\mathrm{Na}_{2} \mathrm{O}+\mathrm{K}_{2} \mathrm{O}, \mathrm{F}=\mathrm{FeO}+\mathrm{Fe}_{2} \mathrm{O}_{3}, \mathrm{M}=\mathrm{MgO}\right)$. The boundary between the tholeiitic and calc-alkaline series is from Kuno (1968). (b) A/CNK-A/NK $\left\{\mathrm{Al}_{2} \mathrm{O}_{3} /\left(\mathrm{CaO}+\mathrm{Na}_{2} \mathrm{O}+\mathrm{K}_{2} \mathrm{O}\right)-\right.$ $\left.\mathrm{Al}_{2} \mathrm{O}_{3} /\left(\mathrm{Na}_{2} \mathrm{O}+\mathrm{K}_{2} \mathrm{O}\right)\right\}$ diagram. (c) Chondrite-normalized REE distribution (Taylor, McLennan, 1985). (d) Spider-diagram of the trace elements normalized to the composition of primitive mantle (Taylor and McLennan, 1985).

dating, carried out by step heating on a resistance furnace at the Stanford University, yielded a spectrum with progressively rising steps from 92 to $161 \mathrm{Ma}$ at the highest temperature without forming a plateau (Fig. 10b). This pattern of rising age steps suggest partial loss of Ar after white mica crystallization due to a thermal disturbance (McDougall and Harrison, 1988). Although these data should be interpreted with caution, it seems that metamorphism in this part of the 


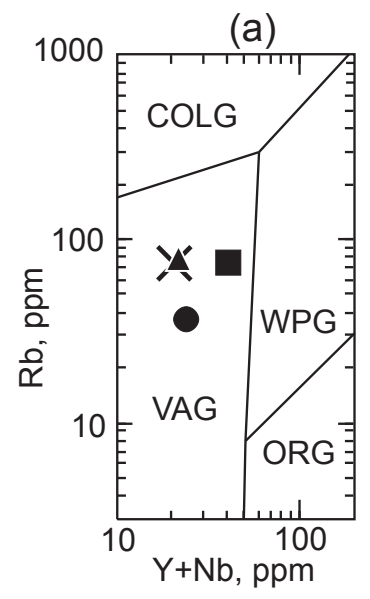

(c)

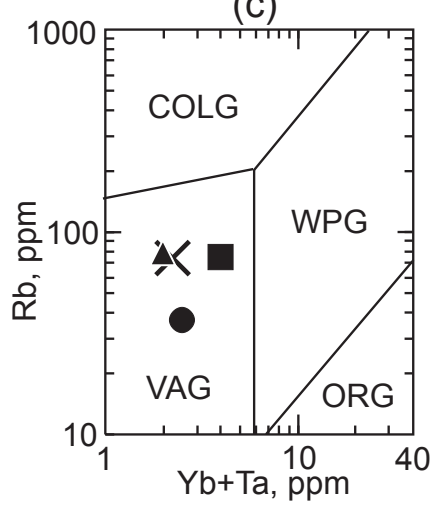

(b)

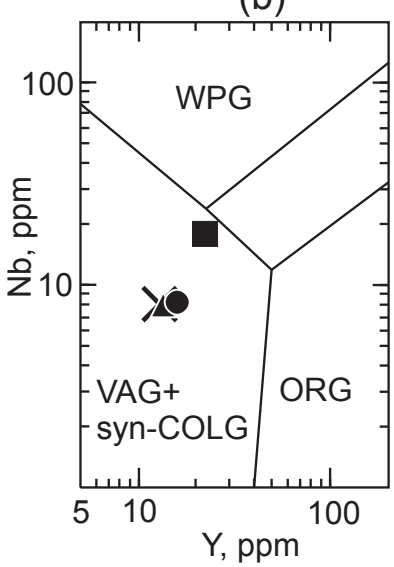

(d)

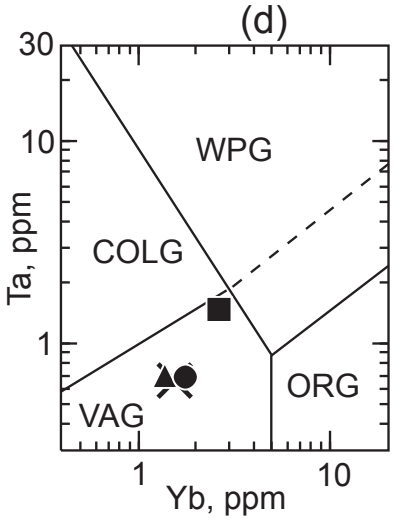

Fig. 8. Tectonic discrimination diagrams for granitoids of the Mastakh pluton after Pearce et al. (1984). All the samples plot in the Volcanic Arc Granite field. For symbols see Fig. 7. VAG=volcanic arc granite, $\mathrm{WPG}=$ within-plate granite, $\mathrm{COLG}=$ collisional granite, $\mathrm{ORG}=$ oceanic ridge granite.

South Verkhoyansk has a Late Jurassic minimum age and was followed by either protracted residence at relatively high temperature, or a second Mesozoic heating event below the Ar closure temperature of muscovite.

Carboniferous and Permian terrigenous rocks of the Allakh-Yun' zone were completely recrystallized and exhibit phyllitic to slaty cleavage. Typical mineral associations in the highest grade zones are quartz + biotite + albite + epidote + muscovite and locally staurolite + garnet + epidote + muscovite + quartz + biotite + albite. Maximum P-T conditions of metamorphism are determined as 3-6 kbar and $500^{\circ} \mathrm{C}$ (Simanovich and Andriyanov, 1984). However, the bulk of the metamorphic belt is in the sericite-chlorite subfacies of the greenschist facies. These rocks are characterized by the quartz + albite + sericite (muscovite) + chlorite association (Parfenov and Prokopiev, 2000).
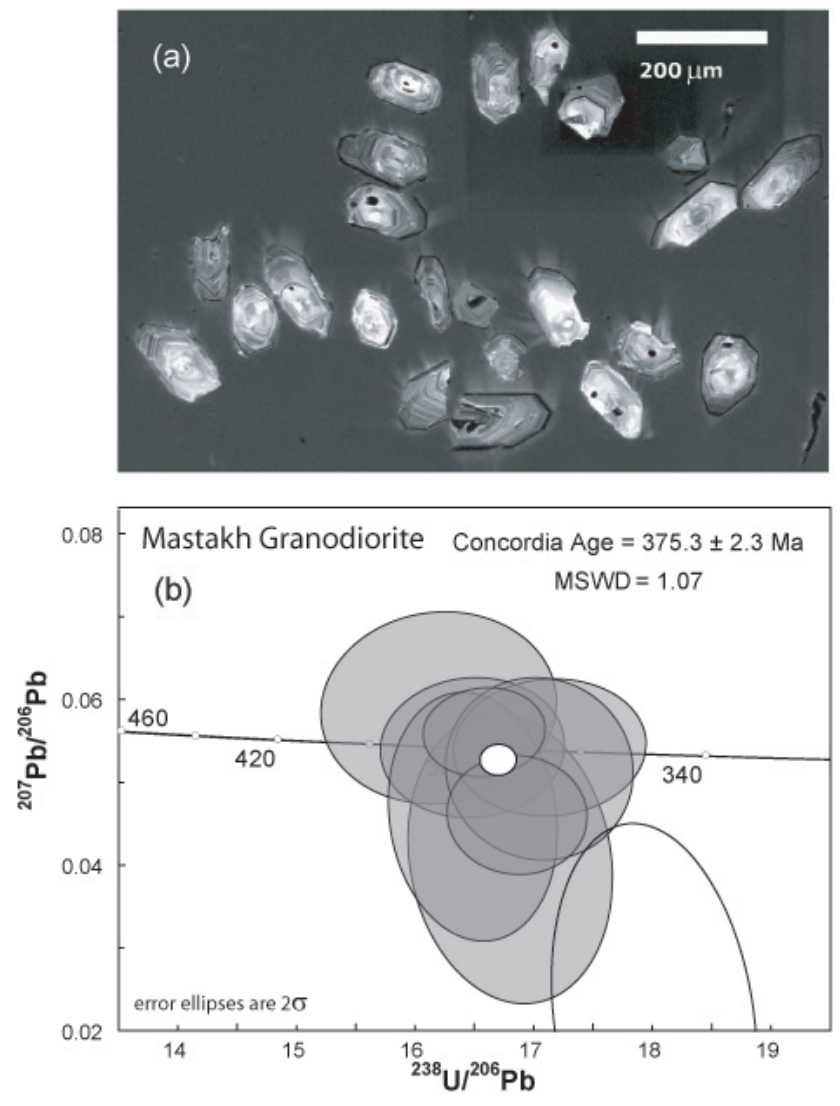

Fig. 9. $\mathrm{U} / \mathrm{Pb}$ zircon data from the Mastakh Granodiorite, sample 182-B-62. (a) Cathodoluminecense image of zircons acquired with a JEOL JSM 5600 scanning electron microscope. (b) TeraWasserburg concordia diagram showing 10 SHRIMP-RG spot analyses. The grey ellipses are the data used in the calculation of the concordia age (white ellipse) using Isoplot (Ludwig, 2001).

Andriyanov (1973b) states that the granitoids of the Uemlyakh and Tarbagannakh plutons (Fig. 2) cut the metamorphic zones and that mineral assemblages characteristic of contact metamorphism are superimposed on the regionally metamorphosed rocks. However, in the eastern flank of the Allakh-Yun' zone we observed that biotite within the dominant foliation in the terrigenous metasedimentary rocks was limited to the proximity of the Tarbagannakh batholith, and that thin granitic dikes were transposed onto foliation planes and boudinaged. We extracted biotite, newly formed on the cleavage planes, from Carboniferous metasandstones located $3.25 \mathrm{~km}$ from the pluton margin (sample 99 JT 38, Table 3) and it yielded a near-plateau with a ${ }^{40} \mathrm{Ar} /{ }^{39} \mathrm{Ar}$ weighted mean age of $119.4 \pm 0.5 \mathrm{Ma}$ which is only slightly younger than the $123 \pm 1 \mathrm{Ma}{ }^{238} \mathrm{U} /{ }^{206} \mathrm{~Pb}$ age of the pluton. Therefore, ductile deformation in the core or the South Verkhoyansk metamorphic belt was on going during emplacement of the granitoid plutons. 


\section{Origin of the Okhotsk terrane}

The nature of the Okhotsk terrane is open to discussion. It was initially regarded as an uplift of the North Asian craton. This conclusion was supported by the similarity of its Archean crystalline basement and Early Proterozoic sedimentary cover to the Siberian platform (Chikov, 1978). Now the Okhotsk terrane is regarded as an independent terrane because it is bounded on the west by a major fault, and because its middle Paleozoic-Mesozoic stratigraphic section differs significantly from that of the adjacent South Verkhoyansk sector (Parfenov, 1991; Nokleberg et al., 2000). In contrast to the South Verkhoyansk sector, the Okhotsk terrane is characterized by reduced thickness of strata, a wide distribution of continental deposits, abundant Late Paleozoic and Mesozoic volcanics, and numerous unconformities. The absence of Silurian to Lower Devonian, Lower and Middle Triassic, and Middle Jurassic deposits in the section suggests episodes of erosion and, possibly, orogenic events that have not been recognized within the adjacent South Verkhoyansk sector.

Some considered the Okhotsk terrane to be an exotic block that moved to its present location from near Australia (Zonenshain at al., 1990; Natapov and Surmilova, 1995). However, paleomagnetic poles for the Okhotsk terrane are concordant with the North Asian craton in the Middle Riphean (Pavlov et al., 1991), and the Carboniferous and Permian flora of the Okhotsk terrane are comparable to those of the Tunguska basin of Siberia, suggesting that the terrane was located close to North Asia in the Late Paleozoic.

We believe that the Okhotsk terrane formed part of the North Asian craton until the Middle Paleozoic. An important Late Devonian rifting event is documented on the North Asian margin (Gaiduk, 1988). The Late Devonian Vilyui basin (Fig. 1), which extends to the southwest from the central part of the Verkhoyansk fold-and-thrust belt is believed to be a failed arm of this rift (Gaiduk, 1988). Rifting was accompanied by an extensive swarm of basaltic dikes that are observed along the entire fold and thrust belt and was followed by rapid subsidence, which led to the deposition of the immense Carboniferous to Jurassic Verkhoyansk sedimentary complex along the new continental margin (Parfenov et al., 1995). In the northern and central parts of Sette-Daban tectonic zone of the South Verkhoyansk sector, there are Devonian-Early Carboniferous volcanogenicsedimentary strata up to $1800 \mathrm{~m}$ thick interbedded with tholeiitic basalts and trachybasalts which are thought to be genetically related to the continental rifting process (Levashov, 1974, 1977; Bulgakova and Kolodeznikov, 1990).It is likely that the Okhotsk terrane was separated from North Asia at this time and moved a relatively small distance away (Fig. 11). Further work along the North Asia/Okhotsk boundary is required to determine whether chert and spilites described in that region (Kogen et al., 1976) contain evidence that rifting reached the oceanic basin stage. The arc signature of Late Devonian magmatic rocks on the Okhotsk
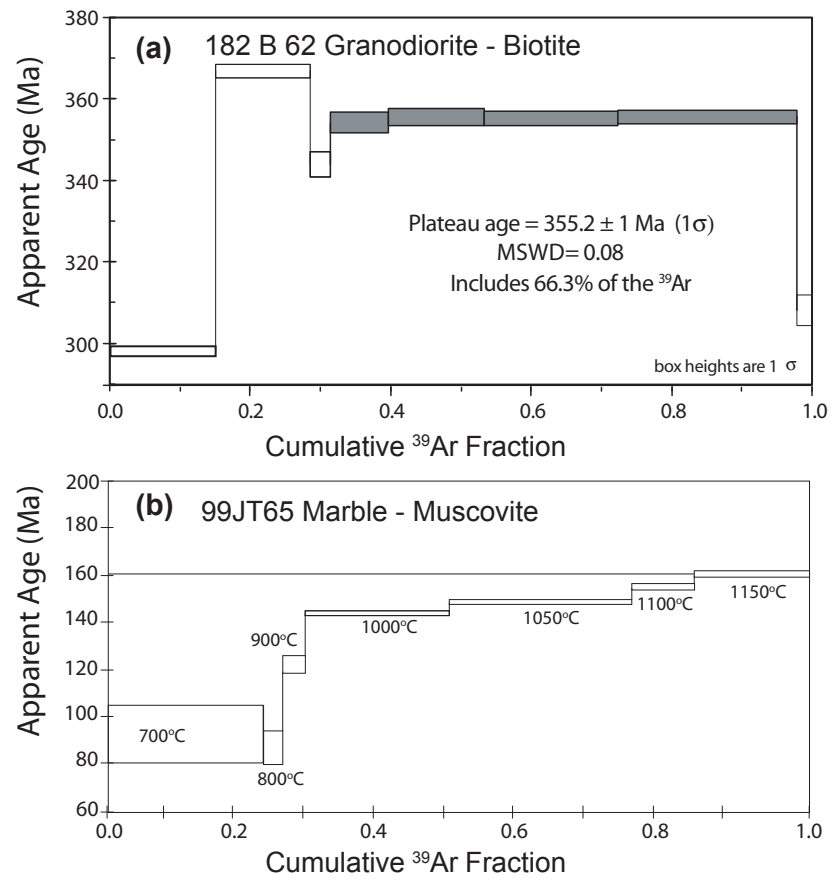

Fig. 10. (a) ${ }^{40} \mathrm{Ar} /{ }^{39} \mathrm{Ar}$ age spectrum for biotite of the Mastakh granodiorite pluton of the Upper Maya uplift. It has a reliable plateau age of $355.2 \pm 1 \mathrm{Ma}$. (b) $\mathrm{The}{ }^{40} \mathrm{Ar} /{ }^{39} \mathrm{Ar}$ age spectrum for muscovitic Ordovician marble from the Sette Daban zone of the South Verkhoyansk has a rising age spectrum with a maximum of $160 \pm 1 \mathrm{Ma}$ at the highest temperature. We interpret this Ar release pattern as evidence of metamorphism of at least Late Jurassic age followed by partial Ar loss, probably due to younger Mesozoic heating.

terrane, including the Mastakh and Maya plutons and the volcanic rocks of the Mati Formation, indicates that a continental margin volcanic arc (Vel'dyaksov and Umitbaev, 1976) due to paleo-Pacific subduction developed at this time. Coeval subduction-related magmatic arcs have been identified on the other terranes located in Northeastern Russia (Sengör and Natal'in, 1996; Nokleberg et al., 2000). Therefore, we would suggest that the separation of Okhotsk from North Asia as back-arc rifting (Fig. 11).

It is likely that the Bilyakchan fault represents a suture resulting from the closure of this basin by oblique collision of the Okhotsk terrane and the craton margin (Parfenov and Prokopiev, 2000). This collision took place during the Latest Jurassic and Early Cretaceous creating the South Verkhoyansk fold-and-thrust belt (Parfenov, 1991). Flat-lying Neocomian volcanic rocks of the Uda belt overlie the boundary of the Okhotsk terrane and the Verkhoyansk fold-and-thrust belt indicating that by Neocomian time the terrane had taken its current position. Our limited ${ }^{40} \mathrm{Ar} /{ }^{39} \mathrm{Ar}$ data suggest that metamorphism in the South Verkhoyansk sector was taking place by Late Jurassic and deformation continued until at least $119 \mathrm{Ma}$. 


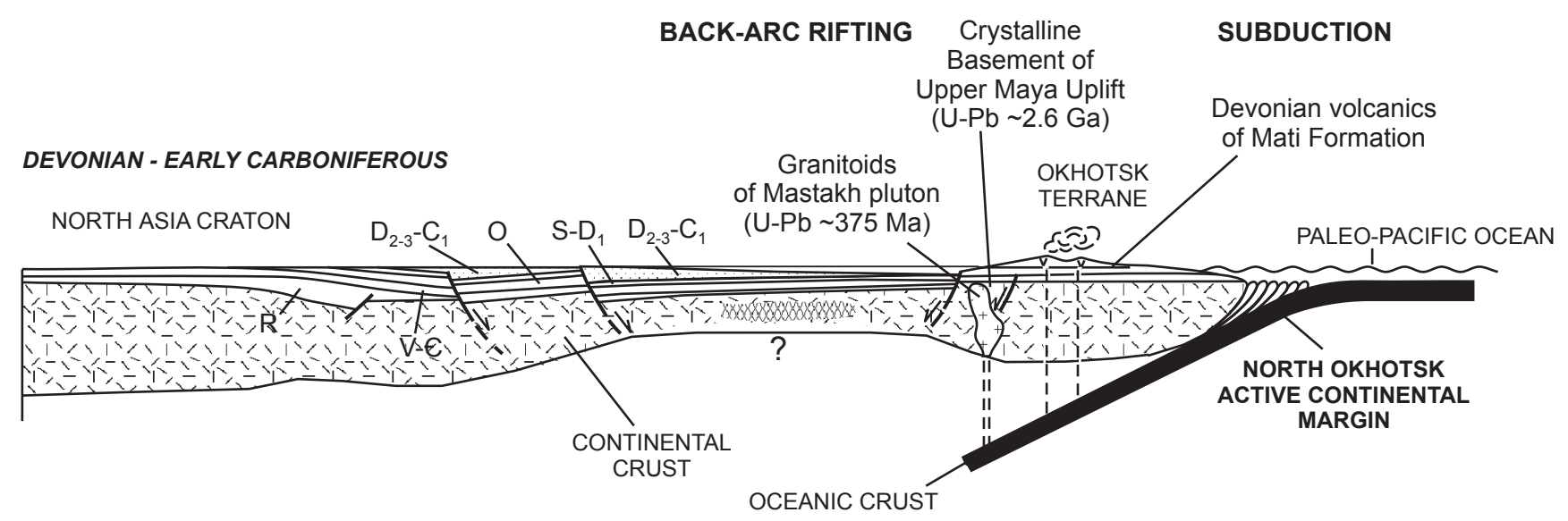

$\begin{array}{ll}\text { LATE PALEOZOIC - MIDDLE JURASSIC } & \text { OKHOTSK } \\ \text { TERRANE } & \text { PALE-PACIFIC OCEAN }\end{array}$
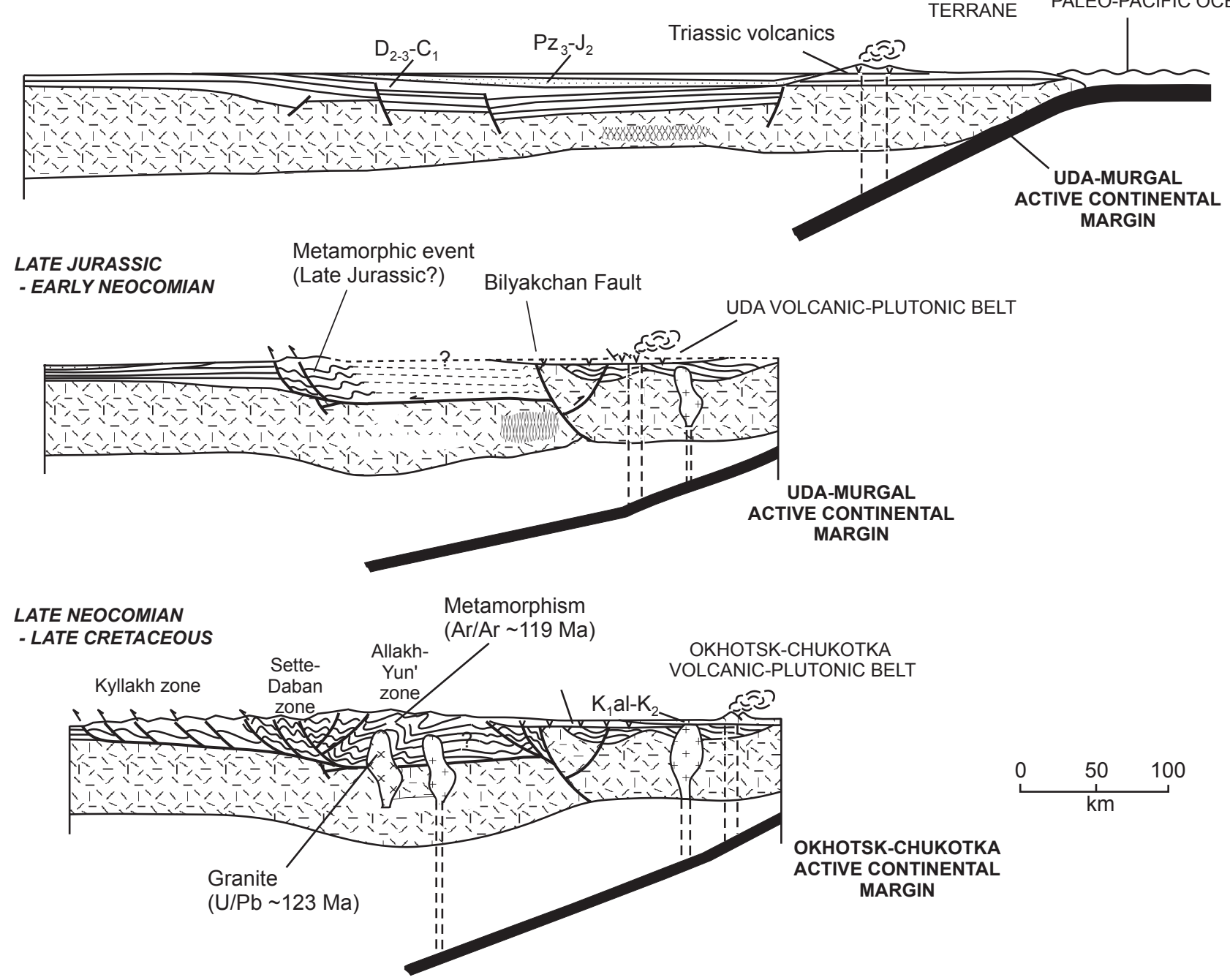

Fig. 11. Tectonic model of the evolution of the South Verkhoyansk fold-and-thrust belt and the Okhotsk terrane. See the text for discussion. Abbreviations: R=Riphean, V-C=Vendian-Cambrian, $\mathrm{O}=$ Ordovician, $S-\mathrm{D}_{1}=$ Silurian-Early Devonian, $\mathrm{D}_{2}-3_{-}-\mathrm{C}_{1}=$ Middle Devonian-Early Carboniferous, $\mathrm{Pz}_{3}-\mathrm{J}_{1}=$ Late Paleozoic-Early Jurassic, $\mathrm{K}_{1}$ al- $\mathrm{K}_{2}=$ Albian-Late Cretaceous. 


\section{Conclusions}

We have confirmed the existence of orthogneisses with Archean protolith ages in the Upper Maya uplift of the Okhotsk terrane. However, the Early Devonian ${ }^{40} \mathrm{Ar} /{ }^{39} \mathrm{Ar}$ biotite age of our sample documents a mid-Paleozoic metamorphic event perhaps linked with the onset of rifting of the Okhotsk terrane from the North Asian craton. Our U-Pb isotopic data indicate that granitoids of the Mastakh pluton are Late Devonian in age while their geochemical characteristics correspond to a continental margin volcanic arc. We believe that these plutons together with the poorly studied Late Devonian calc-alkaline volcanic rocks of the Mati Formation mark a Middle Paleozoic subduction zone that was probably located along the south and southeast margin of the Okhotsk terrane. Therefore, Late Devonian continental rifting in the South Verkhoyansk region can be regarded as back-arc rifting (Fig. 11).

Dynamic metamorphism in the Sette-Daban tectonic zone of the South Verkhoyansk sector began in the Latest Late Jurassic marking the onset of deformation in the hinterland of the South Verkhoyansk sector, and is related to collision and accretion of the Okhotsk terrane to North Asia (Fig. 11). In the Late Neocomian through Aptian, metamorphism and deformation continued in the Allakh-Yun' zone of the South Verkhoyansk metamorphic belt ending with the emplacement of the Tarbagannakh and Uemlyakh batholiths related to subduction along the Uda-Murgal magmatic arc at about $120 \mathrm{Ma}$.

Acknowledgements. The authors thank Kazuya Fujita and Brian A. Hampton for their helpful and thorough reviews of our manuscript. Research was supported by projects RFBR (07-05-00743, 06-05-96070), ONZ-7.10.2. and a grant to Stanford University by Exxon-Mobil.

\section{References}

Andriyanov, N. G.: Dynamothermal metamorphism of terrigenous rocks in the South Verkhoyansk synclinorium, in: News about Geology of Yakutia, Yakutian Publishing House, Yakutsk, 3, 72 74, 1973a (in Russian).

Andriyanov, N. G.: On the relationships between the processes of metamorphism and gold ore mineralization in the South Verkhoyansk synclinorium, Dokl. Akad. Nauk SSSR+, 211(2), 434-436, 1973b (in Russian).

Avchenko, O. V.: Petrology of the metamorphic complex of the Okhotsk massif, Synopsis of Cand. Sci. thesis, Vladivostok: DVGI DVO SSSR, 23, 1975 (in Russian).

Bulgakova, M. D. and Kolodeznikov, I. I.: Middle Paleozoic rifting in the northeast USSR (lithology and volcanism), Nauka, Moscow, 1990 (in Russian).

Chikov, B. M.: Median massifs and problems of tectonic zoning of orogenic belts, Nauka, Novosibirsk, 1978 (in Russian).

Cumming, G. L. and Richards, J. R.: Ore lead ratios in a continuously changing Earth, Earth Planet. Sc. Lett., 28, 155-171, 1975.
Fershtater, G. B.: Granitoid magmatism and formation of continental crust during the development of the Ural orogen, Litosfera, 1, 62-85, 2001 (in Russian).

Flowers, R. M., Bowring, S. A., and Reiners, P. W.: Low long-term erosion rates and extreme continental stability documented by ancient (U-Th)/He dates, Geology, 34, 925-928, 2006.

Gaiduk, V. V.: The Middle Paleozoic Vilyui rift system, YaF SO AN SSSR, Yakutsk, 1988 (in Russian).

Gorodinsky, M. E. (ed.): Geologic map of the northeast USSR, scale: 1:1 500 000, VSEGEI, Leningrad, 1980 (in Russian).

Grinberg, G. A.: The Precambrian of the Okhotsk Massif, Nauka, Moscow, 1968 (in Russian).

Gusev, G. S.: Fold structures and faults of the Verkhoyansk-Kolyma Mesozoic system, Nauka, Moscow, 1979 (in Russian).

Hacker, B. R., Mosenfelder, J. L., and Gnos, E.: Rapid emplacement of the Oman ophiolite: Thermal and geochronologic constraints, Tectonics, 15, 1230-1247, 1996.

Hourigan, J. K., Reiners, P. W., and Brandon, M. T.: U-Th zonationdependent alpha-ejection in (U-Th)/He ages, Geochim. Cosmochim. Ac., 60, 4223-4229, 2005.

Ireland, T. R. and Williams, I. S.: Considerations in zircon geochronology by SIMS, in: Zircon, edited by: Hanchar, J. M. and Hoskins, P. W. O., Rev. Mineral. Geochem., 53, 215-241, 2003.

Katkov, S. M., Strickland, A., Miller, E. L., and Toro, J.: Structural setting and U-Pb SHRIMP geochronology of granitoid plutons in the Anyui-Chukotka fold belt, Bilibino region, NE Russia, submitted, this volume, 2009.

Kogen, V. S., Runov, B. E., and Stavtsev, A. L.: New data on the geology and ore content of the Bilyakchan fault zone (South Verkhoyansk), Izv. AN SSSR Geol.+, 8, 113-123, 1976 (in Russian).

Komar, V. A. and Rabotnov, V. T.: The Upper Precambrian of the northeast USSR, Izv. AN SSSR Geol.+, 8, 9-16, 1976 (in Russian).

Korostelev, V. I.: Some problems of tectonics and magmatism in the junction zone of the South Verkhoyansk synclinorium and the Aldan shield, in: Tectonomagmatic and Metallogenic Problems of the Geology of Yakutia, YaGU, Yakutsk, 3-17, 1987 (in Russian).

Kuno, H.: Differentiation of basalt magmas, in: Basalts: The Poldervaart treatise on rocks of basaltic composition, edited by: Hess, H. H. and Poldervaart, A., Interscience, New York, 2, 623-688, 1968.

Kuz'min, V. K.: Geology of the crystalline basement in the Yurovsk uplift (Okhotsk massif), Tikhookean. Geol., 5, 67-77, 1993 (in Russian).

Kuz'min, V. K., Belyatskiy, B. V., and Naumov, M. V.: First Sm$\mathrm{Nd}$ data on Late Ordovician age of granitoids of the Upper Maya uplift (Okhotsk massif), Dokl. RAN, 390(2), 228-232, 2003 (in Russian).

Kuz'min, V. K., Chukhonin, A. P., and Shuleshko, I. K.: Stages of metamorphic evolution of the rocks of the crystalline basement in the Kukhtuy uplift (Okhotsk massif), Dokl. RAN, 342(62), 789-791, 1995 (in Russian).

Levashov, K. K.: Middle Paleozoic riff zone of the Sette-Daban, Dokl. Akad. NAUK SSSR+, 219(3), 689-692, 1974 (in Russian).

Levashov, K. K.: Paleo-rift structure of eastern frame of Siberian platform, Sovetskaya Geologiya, 10, 59-75, 1977 (in Russian). 
Ludwig, K. R.: Isoplot 3.00, a geochronological toolkit for Excel, Berkeley Geochronology Center Special Publication no. 4, 2003.

Martynyuk, M. V., Ryamov, S. A., and Kondratieva, V. A.: Explanatory notes to the differentiation and correlation scheme of magmatic complexes of the Khabarovsk Territory and Amur Region, Khabarovsk, 1990 (in Russian).

McDougall, I. and Harrison, T. M.: Geochronology and thermochronology by the ${ }^{40} \mathrm{Ar} /{ }^{39} \mathrm{Ar}$ method, Oxford Monographs on Geology and Geophysics, 9, 1988.

NAVDAT, Western North America Volcanic and Intrusive Rock Database, steering committee: Walker, J. D., A. F. Glazner, G. L. Farmer, R. W. Carlson and L. Ferrari, available at: http: //navdat.kgs.ku.edu/index.cfm, 2007.

Natapov, L. M. and Surmilova, E. P.: Position and nature of the Okhotsk massif, Otechestvennaya Geologiya, 2, 49-53, 1995 (in Russian).

Nemenman, I. S.: On the method of field mapping of weak metamorphic transformations in the southern Allakh-Yun' zone, in: Metamorphic complexes of the Northeast USSR, their ore content and geologic mapping, SVKNII DVO AN SSSR, Magadan, 97-106, 1991 (in Russian).

Nenashev, N. I. and Zaitsev, A. I.: Geochronology and problem of genesis of East Yakutian granitoids, Nauka, Novosibirsk, 1980 (in Russian).

Nokleberg, W. J., Parfenov, L. M., Monger, J. W. H., et al.: Phanerozoic tectonic evolution of the Circum-North Pacific, Professional Paper 1626, USGS, 2000.

Paces, J. B. and Miller Jr., J. D.: Precise U-Pb ages of Duluth complex and related mafic intrusions, northeastern Minnesota: Geochronological insights to physical, petrogenetic, paleomagnetic, and tectonomagmatic processes associated with the $1.1 \mathrm{Ga}$ midcontinent rift system, J. Geophys. Res., 98(B8), 1399714014, 1993.

Parfenov, L. M.: Tectonics of the Verkhoyansk-Kolyma Mesozoides in the context of plate-tectonics, Tectonophysics, 139, 319-342, 1991.

Parfenov, L. M., Prokopiev, A. V., and Gaiduk, V. V.: Cretaceous frontal thrusts of the Verkhoyansk fold belt, eastern Siberia, Tectonics, 14, 342-358, 1995.

Parfenov, L. M. and Prokopiev, A. V.: Geology and metallogenesis of the South Verkhoyansk sector of the Verkhoyansk fold-andthrust belt, in: Nezhdaninka gold deposit - a unique deposit in northeast Russia, GEOS, Moscow, 10-34, 2000 (in Russian).

Parfenov, L. M. and Kuzmin, M. I.: Tectonics, geodynamics and metallogeny of the Sakha Republic (Yakutia) - MAIK Nauka, Interperiodica, Moscow 2001 (in Russian).

Pavlov, V. E., Manukyan, A. M., Sharkovskiy, M.B., and Levashova, N. M.: First paleomagnetic data on the Riphean of the Okhotsk massif, Dokl. Akad. Nauk SSSR+, 317(3), 688-692, 1991 (in Russian)

Pearce, J. A., Harris, N. B. W., and Tindle, A. G.: Trace element discrimination diagrams for the tectonic interpretation of the granitic rocks, J. Petrol., 25(44), 956-963, 1984.

Prokopiev, A. V.: Kinematics of Mesozoic folding in the western part of the South Verkhoyansk region, YaNTs SO AN SSSR, Yakutsk, 1989 (in Russian).

Prokopiev, A. V., Toro, J., Miller, E. L., Hourigan J. K., Tarabukin, V. P., and Dumitru, T. A.: Deformation style of the Verkhoyansk fold-and-thrust belt (northeast Russia), Otechestvennaya Geologiya, 5, 47-52, 2001 (in Russian).

Reiners, P. W.: Zircon (U-Th)/He Thermochronometry, in: Thermochronology, edited by: Reiners, P. W. and Ehlers, T. A., Rev. Mineral. Geochem., 58, 151-176, 2005.

Sagir, A.: Ancient deep faults, their reactivation and peculiarities under different geodynamic conditions in Eastern Yakutia (Northeast Russia), Polarforschung, 69, 177-184, 2001.

Sengör, A. M. C. and Natal'in, B. A.: Paleotectonics of Asia: Fragments of a synthesis, in: The tectonic evolution of Asia, edited by: Yin, A. and Harrison, M., Cambridge University Press, 486640, 1996.

Simanovich, I. M. and Andriyanov, N. G.: Initial metamorphism of the rocks of the Verkhoyansk complex (South Verkhoyansk region), Litologiya i poleznye iskopaemye, 3, 103-115, 1984 (in Russian).

Sosunov, G. M., Pavlova, O. K., and Gel'man, M. L.: Geologic map of the northeast USSR in scale 1:1500000. Tables of regional legend, Magadan: SVKNII DVO AN SSSR, 39 pp., 1982 (in Russian).

Taylor, S. R. and McLennan, S. M.: The Continental Crust: Its Composition and Evolution, Blackwell, Oxford, 1985.

Toro, J., Prokopiev, A. V., Miller, E. L., and Dumitru, T. A.: Structure and thermochronology of the South Verkhoyansk thrust belt, Eastern Siberia, GSA Fall Meeting 2001, Boston, USA, Abstracts, 33(6), 185, 2001.

Tuchkov, I. I. and Andrianova, V. A.: New data on effusive rocks in the upper Maya river, in: Petrography and mineralogy of sedimentary formations of Yakutia, Yakutian Publishing House, Yakutsk, 87-97, 1972 (in Russian).

Umitbaev, R. B.: Geological formations of the Okhotsk median massif, in: Tectonics of the eastern Soviet Asia, Vladivostok: DVO AN SSSR, 73-95, 1976 (in Russian).

Vel'dyaksov, F. F. and Peskov, E. G.: Stratigraphy and magmatism of the Kukhtuy uplift of the Okhotsk massif, in: Metamorphic complexes of the eastern USSR, Vladivostok: DVGI DVO AN SSSR, 81-89, 1973 (in Russian).

Vel'dyaksov, F. F. and Umitbaev, R. B.: Main features of tectonics and metallogenesis of the Okhotsk massif, in: Fold systems of the Far East., Vladivostok, 93-117, 1976 (in Russian).

Verzhkhovskaya, V. A. and Krichevets, V. I.: State Geologic Map of the USSR, Sheet O-(53), 54 - Okhotsk, scale: 1:1 000000 (new series), VSEGEI, Leningrad, 1982 (in Russian).

Zagruzina, I. A.: Radiometric age of Precambrian metamorphic complexes in the northeast USSR, in: Geology of the Precambrian and tectonics of the Far East, Vladivostok: DVO AN SSSR, 20-26, 1975 (in Russian).

Zonenshain, L. P., Kuzmin, M. I., and Natapov, L. M.: Geology of the USSR: A Plate Tectonic Synthesis, Geodynamic Series 21, American Geophysical Union, Washington, DC, 1990. 